\title{
DFT Studies of Carbon Structures Supported Vanadia Catalysts for Oxidative Dehydrogenation of Propane: Kinetic and Thermodynamic
}

\author{
Yoğunluk Fonksiyon Teorisi (DFT) ile Propanın Oksidatif \\ Dehidrojenasyonu için Karbon Yapı Destekli Vanadyum \\ Katalizörlerinin Çalışılması: Kinetik ve Termodinamik \\ Research Article
}

\author{
Abdollah Fallah Shojaei ${ }^{*}$, Ali-Morad Rashidi ${ }^{2}$, Mina Ghiasi ${ }^{3}$, Robabe Mosavi ${ }^{1}$ \\ 'Department of Chemistry, Faculty of Sciences, University of Guilan, Rasht, Iran. \\ ${ }^{2}$ Research Institute of Petroleum Industry (RIPI), Nanotechnology Research Center, Tehran, Iran. \\ ${ }^{3}$ Department of Chemistry, Faculty of Physics \& Chemistry, Alzahra University, Tehran, Iran.
}

\section{A B S TR AC T}

\begin{abstract}
The detailed mechanism for oxidative dehydrogenation of propane on the ${ }^{1} \mathrm{VO}_{4}\left(\mathrm{CH}_{3}\right)_{3}$ surface has been studied in depth with density functional theory (DFT) calculations at the B3LYP level and standard split-valance basis set, 6-31+G*. Monomeric vanadia specie was considered and modeled as catalysis. In addition, the mechanisms of the two complete catalytic cycle, involving the regeneration of the reduced catalyst using $\mathrm{O}_{2}$ gaseous have been reported. The reaction proceeds in two subsequent steps which at the first, one hydrogen abstracting by the vanadium of $\mathrm{V}=01$ group with about $48.35 \mathrm{cal} / \mathrm{mol}$ activation energy is the rate determining step. Subsequently, second intermediate has been formed through a bond formed between the propyl radical and $\mathrm{O}_{2}$ atom (V-O2). In continue, the 01 atom abstracts one hydrogen atom from the methyl group with a $131.63 \mathrm{kcal} /$ mol barrier to form propene by passing to second transition state. The results of our calculations have found that all the reactions involve vanadyl oxygen $(\mathrm{V}=\mathrm{O}$ ), with the bridging oxygen $(\mathrm{V}-\mathrm{O}-\mathrm{C})$ serving to stabilize the isopropyl radical intermediate.
\end{abstract}

\section{Key Words}

Vanadia, propane, oxidative dehydrogenation, DFT calculation.

\section{öz}

u çalışmada propanın ${ }^{1} \mathrm{VO}_{4}\left(\mathrm{CH}_{3}\right)_{3}$ yüzeyindeki oksidatif dehidrojenasyonu, bölünmüş valans temel kümesi 6-31+G* ve B3LYP seviyesinde Yoğunluk Fonksiyon Teorisi hesaplamaları ile incelenmiştir. Monomerik vanadyum türleri kataliz için gözönüne alınmış ve modellenmiştir. Bunlara ek olarak $\mathrm{O}_{2}$ gazı kullanılarak yenilenen indirgenmiş katalizör içeren iki tamamlanmış katalitik döngü sunulmuştur. Tepkime iki alt basamakta ilerlemektedir; birinci basamakta bir hidrojen 48,35 cal/mol aktivasyon enerjisiyle $V=01$ vanadyum grubu tarafından alıkonulur ve hız belirleyici basamaktır. Sonrasında propil radikali ve $\mathrm{O}_{2}$ atomu arasında (V-O2) oluşan bağ dolayısıyla ikinci ara ürün oluşur. Devamında 01 atomu propen oluşumu ve ikinci geçiş haline ulaşmak için metil grubundan $131.63 \mathrm{kcal} / \mathrm{mol}$ enerjiyle bir hidrojen koparır. Sonuçların, bütün tepkimelerde izopropil ara radikali kararlı kale getirmek için vanadil oksijen $(V=01)$ ve köprüleme oksijeni $(V-O-C)$ kullanıldığını göstermiştir.

\section{Anahtar Kelimeler}

Vanadyum, propan, oksidatif dehidrasyon, yoğunluk fonksiyonel teorisi.

Article History: Received: Jun 21, 2017; Revised: Oct 28, 2017; Accepted: Feb 08, 2017; Available Online: Feb $20,2018$.

DOI: $10.15671 / \mathrm{HJBC} .2018 .216$

Correspondence to: A.F. Shojaei, Department of Chemistry, Faculty of Sciences, University of Guilan, Rasht, Iran. 


\section{INTRODUCTION}

The oxidative dehydrogenation (ODH) of propane is a particular alternative to the direct catalytic dehydrogenation, which is the main process step in the highly efficient and technically mass production of many intermediates and petrochemicals such as acrylonitrile, propylene oxides and propylene. The catalytic activation of $\mathrm{C}-\mathrm{H}$ bonds is of fundamental interest because it is the crucial step in important technological processes and in many enzymatic reactions [1]. In general, for producing the chemicals for polymer and fine organic synthesis, short-chain hydrocarbons, mainly ethane [2], propane [3] and butane $[4,5]$ have been considered as substrates in oxidative dehydrogenation reactions. In propylene preparation, propane oxidation often serves as a model for carbon-catalyzed oxidation reactions. The following reaction is thermal cracking of propane with and without oxygen [6, 7]:

$$
\begin{array}{ll}
\mathrm{C}_{3} \mathrm{H}_{8} \rightarrow \mathrm{C}_{3} \mathrm{H}_{6}+\mathrm{H}_{2} & \Delta \mathrm{H}=+30 \mathrm{kcal} / \mathrm{mol} \\
2 \mathrm{C}_{3} \mathrm{H}_{8}+1 / 2 \mathrm{O}_{2} \rightarrow \mathrm{C}_{3} \mathrm{H}_{6}+\mathrm{H}_{2} \mathrm{O} & \Delta \mathrm{H}=-28 \mathrm{kcal} / \mathrm{mol}
\end{array}
$$

It should be noted that dehydrogenation of propane in propylene preparation is a conventional method which suffers from highenergy consumption, thermodynamic restrictions and pyrolysis side reactions such coke deposition. Applying dehydrogenation process in the presence of oxygen overcomes the mentioned above difficulties $[8,9]$. Propane is dehydrated to propylene under following oxidation dehydrogenation $(\mathrm{ODH})$ conditions:

$$
\begin{aligned}
& 2 \mathrm{C}_{3} \mathrm{H}_{8}+\mathrm{O}_{2} \rightarrow 2 \mathrm{C}_{3} \mathrm{H}_{6}+2 \mathrm{H}_{2} \mathrm{O} \\
& \mathrm{C}_{3} \mathrm{H}_{8}+5 \mathrm{O}_{2} \rightarrow 3 \mathrm{CO}_{2}+4 \mathrm{H}_{2} \mathrm{O} \\
& 2 \mathrm{C}_{3} \mathrm{H}_{6}+9 \mathrm{O}_{2} \rightarrow 6 \mathrm{CO}_{2}+6 \mathrm{H}_{2} \mathrm{O} \\
& 4 \mathrm{C}_{3} \mathrm{H}_{8}+2 \mathrm{O}_{2} \rightarrow \mathrm{C}_{2} \mathrm{H}_{4}+\mathrm{CO}_{2}+2 \mathrm{H}_{2} \mathrm{O} \\
& 2 \mathrm{C}_{3} \mathrm{H}_{6}+3 \mathrm{O}_{2} \rightarrow 2 \mathrm{C}_{2} \mathrm{H}_{4}+2 \mathrm{CO}_{2}+2 \mathrm{H}_{2} \mathrm{O}
\end{aligned}
$$

Different supports have been used in oxidative dehydrogenation of propane including alumina, titania, vanadia, silica and so on [1,10-13]. Among various supports used as heterogeneous catalysts, carbon materials are in high interest due to their large surface area and chemical stability, which results in high active sites loading. Besides, this property assists their resistance in both acidic and basic media. Carbon nanotubes, graphene and porous graphene are the examples of carbon materials which are produced and exploited at industrial scales for various applications $[14,15]$. In this study, transition metal oxides, that is to say, supported vanadia, are studied as catalysts [16]. Supported vanadia is the most selective and active material because of its elevated activity and selectivity in ODH of light alkanes to alkenes. The reason for This outstanding property is vanadium can provide lattice oxygen in removing hydrogen from propane $[9,17,18]$. It is worth indicating that carbon materials and metal oxides present the same characteristics regarding their catalytic properties and surface structures, which make them great candidates to be used in $\mathrm{ODH}$ reactions [19]. So far, the effect of support and methods on preparation of vanadia supported materials has been investigated in some studies which convincing results have been released [20]. For example, $\mathrm{V}_{2} \mathrm{O}_{5}$ supported on $\mathrm{TiO}_{2}$ is a promising catalyst for ODHP process [21]. Other supported for vanadium oxide such as $\mathrm{Al}_{2} \mathrm{O}_{3}, \mathrm{TiO}_{2}$ are studied, as well [22-24]. Although substantial progress has been made in using carbon materials as catalyst support such as carbon nanotubes and graphenesupported catalysts [25] in ODH reactions. In order to have a better perspective about experimental laboratory researches and the mechanism of

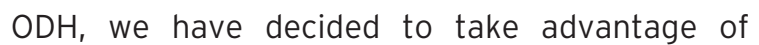
computational methods to check the possibility of the reaction and possible pathways, theoretically. In some studies the application of computational chemistry has been used to understand the catalytic reactions in details, thus, computational experiments have been applied on transition metal oxides for their surface structure and designing catalysts $[26,27]$.

Among different computational methods, DFT is a common method in determining catalyst structure, explanation of spectroscopic information, investigation of reaction networks and mechanisms $[1,4,28]$. This information can provide useful information about the characteristics of catalysts such as the nature of active center and its catalytic activity. DFT method also declares the interaction between oxygen and carbon surfaces, edge sites and reaction 

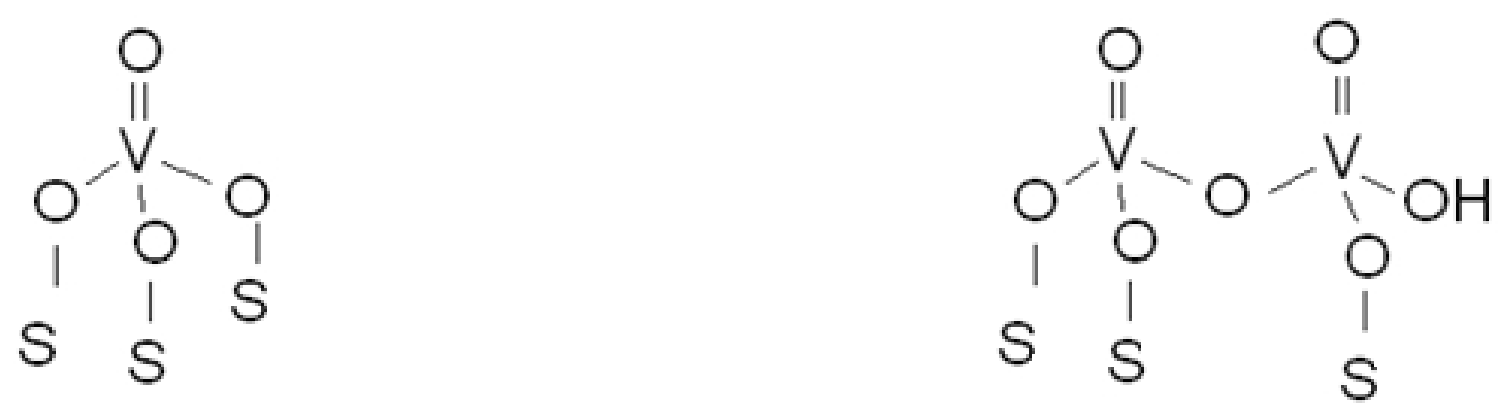

Figure 1. Presentation of monomeric and dimeric structures of tetrahedral VOx model system ( $\mathrm{S}$ is $\mathrm{CH}_{3}$ as support).

mechanism of oxidative dehydrogenation. The possible mechanism for $\mathrm{ODH}$ with $\mathrm{SiO}_{2}$ supported vanadium oxide is reported by Rozanska et al $[1,29]$ using silsesquioxane $\mathrm{H}_{8} \mathrm{Si}_{8} \mathrm{O}_{12}$ cluster model by B3LYP method. In recent experimental results, it has been confirmed that three types of vanadium species comprising monovanadate, one- and twodimensional vanadate chains (polyvanadate), and crystallites of $\mathrm{V}_{2} \mathrm{O}_{5}$ are present on supports in $\mathrm{V}_{2} \mathrm{O}_{5} /$ $\mathrm{TiO}_{2}$, and $\mathrm{V}_{2} \mathrm{O}_{5} / \mathrm{Al}_{2} \mathrm{O}_{3}$ that depends on $\mathrm{V}_{2} \mathrm{O}_{5}$ loading on support [30]. Oyama et al found that a single vanadium center for ethylene ODH is necessary on the basis of relationship between vanadium oxide concentration on an $\mathrm{SiO}_{2}$ support and the ethylene turnover rate [31-33]. Monovanadates have higher activity and better selectivity to ODH of propane on $\mathrm{V}_{2} \mathrm{O}_{5} / \mathrm{ZrO}_{2}$ catalysts than bulk $\mathrm{V}_{2} \mathrm{O}_{5}$ and polyvanadates [34].

Other studies show that the polyvanadate structures are significantly more active than monovanadate structure. This conclusion can be taken that one of the monovanadates or polyvanadates is better but know that these sites are more important than crystalline $\mathrm{V}_{2} \mathrm{O}_{5}$. In spite of large studies in this field, there are some uncertainties in the details of mechanism of ODH reactions. The common structure of supported vanadium oxide is coordinated vanadia in tetrahedral geometry with terminal vanadyl oxygen $(\mathrm{V}=\mathrm{O})$ and three bridge oxygen atoms which are connected to cautions through $\mathrm{V}$-O-S ( $\mathrm{S}$ is support) or neighbor $\mathrm{V}_{2} \mathrm{O}_{5}$ units $(\mathrm{V}-\mathrm{O}-\mathrm{V})$ as monomeric and dimeric structures (Figure 1). In the present study, our attention focuses on several mechanistic aspects to achieve a complete understanding on the molecular scale; (1) the details of mechanism of ODH reactions, (2) study of different transition states and intermediates through the reaction path. To achieve these goals, we have investigated the mechanism of activating the $\mathrm{C}-\mathrm{H}$ bond of propane with subsequent formation of propene. The results of this model can be used in mechanisms of supported vanadia catalysts.

\section{Computational Methods}

All calculations were performed using the Gaussian 98 [20] software. The geometries and energies of model system of reactants, transition states, intermediates and products were calculated by employing a hybrid HartreeFock- density functional scheme, the adiabatic connection method-Becke three-parameter with Lee-Yang-Parr (B3LYP) functional [35] of density functional theory (DFT) [36] with the standard 6-31+G* basis set. Any symmetry constrains were applied to full optimization. The B3LYP functional has been demonstrated to provide accurate description for compounds including transition metals and involving hydrogen bond interactions [34-36]. The QST3 procedure has been used to search for transition states. Intrinsic reaction coordinate (IRC) calculations [37] were employed to ensure the identity of the reactants and products corresponding to each transition structure. Vibrational analyses were performed on all optimized structures with the same functional and basis set as the corresponding geometry optimizations. In addition, the thermodynamic properties of all compounds were obtained from frequency calculations at $298.15 \mathrm{~K}$ and 1.0 atmosphere pressure. All reported enthalpies were zero-point (ZPE) corrected with unscaled frequencies. 


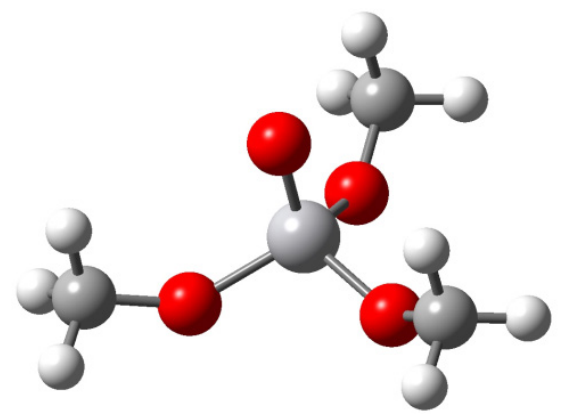

Figure 2. Optimized structure of vanadium oxide supported on carbon atom at the B3LYP/6-31+G* method with some structural details.

\section{RESULTS and DISCUSSION} Optimization of $\mathrm{VO}_{4}\left(\mathrm{CH}_{3}\right)_{3}$ as a Model System The $\mathrm{VO}_{4}\left(\mathrm{CH}_{3}\right)_{3}$ in Figure 1 (left) was considered as a topological model to investigate top surface layer of vanadia surface mapped on to carbon structures. With the aim of reducing computational expenses, instead of using carbons of carbon materials, $\mathrm{CH}_{3}$ was placed. The model contains the vanadyl $(\mathrm{V}=\mathrm{O})$ and the $\mathrm{V}-\mathrm{O}-\mathrm{C}$ sites. Vanadium atom in $\mathrm{VO}_{4}\left(\mathrm{CH}_{3}\right)_{3}$ model have a formal oxidation state of +5 , one of oxygen atoms is connected to vanadium via double bond and other three oxygen atoms are connected to carbons through single bond. The optimize geometry as well as some structural details of the $\mathrm{VO}_{4}\left(\mathrm{CH}_{3}\right)_{3}$ model system is presented in Figure 2. The bond distances for $\mathrm{V}=\mathrm{O}$ and $\mathrm{V}-\mathrm{O}$ are equal $1.59 \AA$ and $1.80 \AA$ respectively that is in good agreement with the experimental values of $\mathrm{V}=\mathrm{O}=1.58 \AA$ and $\mathrm{V}-\mathrm{O} 1.78 \AA$ obtained for the bulk $\mathrm{V}_{2} \mathrm{O}_{5}$ [37]. Also periodic DFT calculations on the $V_{2} O_{5}(001)$ surface lead to $V=0=1.59 \AA$ and $\mathrm{V}-\mathrm{O}=1.80 \AA$ [38]. The result of natural bond orbital analysis (NBO) shows QV $=1.41, \mathrm{QO1}=-0.31$ and $\mathrm{QO} 2=-0.73$ electrons. This result is in good agreement with the values of shows $Q V=1.46$, $\mathrm{QO1}=-0.39$ and $\mathrm{QO2}=-0.71$ electrons that derived from electrostatic field analyzing. Therefore, each $\mathrm{V}-\mathrm{O}$ bond could have a charge transfer of 0.37 electrons from $\mathrm{V}$ to $\mathrm{O}$ atom. While the net transfer in the $\mathrm{V}=\mathrm{O}$ bond is 0.31 electrons despite two polar covalent bonds. It is noticeable that the small charge transfer from $\mathrm{V}$ to $\mathrm{O}$ atom is due to the high oxidation number. Calculation of vibrational frequencies has confirmed stationary point with no negative eigenvalue observed in the force constant matrix. Results of frequency calculations show four vibrational frequencies in the range of $1015-1042 \mathrm{~cm}^{-1}$ for the $V=0$ bond stretching; comparison with experimental values of $1040 \mathrm{~cm}^{-1}$ for bulk $\mathrm{V}_{2} \mathrm{O}_{5} 1010 \mathrm{~cm}^{-1}$ for $\mathrm{V}_{2} \mathrm{O}_{5} / \mathrm{ZrO}_{2}[16]$ and 1042 $\mathrm{cm}^{-1}$ for $\mathrm{V}_{2} \mathrm{O}_{5} / \mathrm{SiO}_{2}$ shows good agreement $[34,39]$. On the basis of the geometrical and energetic similarities of the $\mathrm{VO}_{4}\left(\mathrm{CH}_{3}\right)_{3}$ model to $\mathrm{V}_{2} \mathrm{O}_{5}(001)$, we conclude that the $\mathrm{VO}_{4}\left(\mathrm{CH}_{3}\right)_{3}$ model is a suitable model for studding alkane $\mathrm{ODH}$ reaction and gaining insight in to the whole mechanism.

\section{Oxidative Dehydrogenation of Propane on $\mathrm{VO}_{4}\left(\mathrm{CH}_{3}\right)_{3}$}

\section{Abstraction of the First Hydrogen from Propane}

Two types of addition reactions that involve heterolytic $\mathrm{C}-\mathrm{H}$ bond cleavage from first type and second type of carbon that leads to $\cdot \mathrm{CH}_{2} \mathrm{CH}_{2} \mathrm{CH}_{3}$ and $\mathrm{CH}_{3} \cdot \mathrm{CHCH}_{3}$ radicals and two kinds of hydrogen abstraction reactions that involve hemolytic $\mathrm{C}-\mathrm{H}$ bond cleavage. The optimized geometries as well as relative calculated energies of four reaction paths are depicted in Figure 3. Path (1) and path (2) involve an addition reaction utilizing $V=01$ group, where the hydrogen atom of propane group binds to 01 . In path (1), the hydrogen atom binds to first type of carbon ( $\mathrm{H} 1)$ connected to $\mathrm{O} 1$ atom. The $\mathrm{V}=01$ bond distance in transition state geometry (TS11) in path (1) is $1.55 \AA$; the V-02 bond distance elongates from 1.74 to $1.86 \AA$. The $\mathrm{C}-\mathrm{H}$ bond distance elongates from 1.09 to $1.50 \AA$ and the $\mathrm{C}-\mathrm{O} 2$ bond distances elongate 1.40 to $1.43 \AA$. The activation barrier for path (1) is about 48.35 $\mathrm{kcal} / \mathrm{mol}$. Path 2 is also $\mathrm{V}=01$ addition reaction, but hydrogen of second type of carbon $(\mathrm{H} 2)$ attacks to 01 atom. In the transition state (TS12) the $\mathrm{V}=01$ bond is $1.86 \AA$; the $\mathrm{V}-\mathrm{O} 2$ bond elongates from 1.55 $\AA$ to $1.86 \AA$; the $\mathrm{C}-\mathrm{H}$ bond distance elongates from 1.09 to $1.60 \AA$ and the $\mathrm{CH}_{3}{ }^{-} \mathrm{O}$ (2) bond distances 


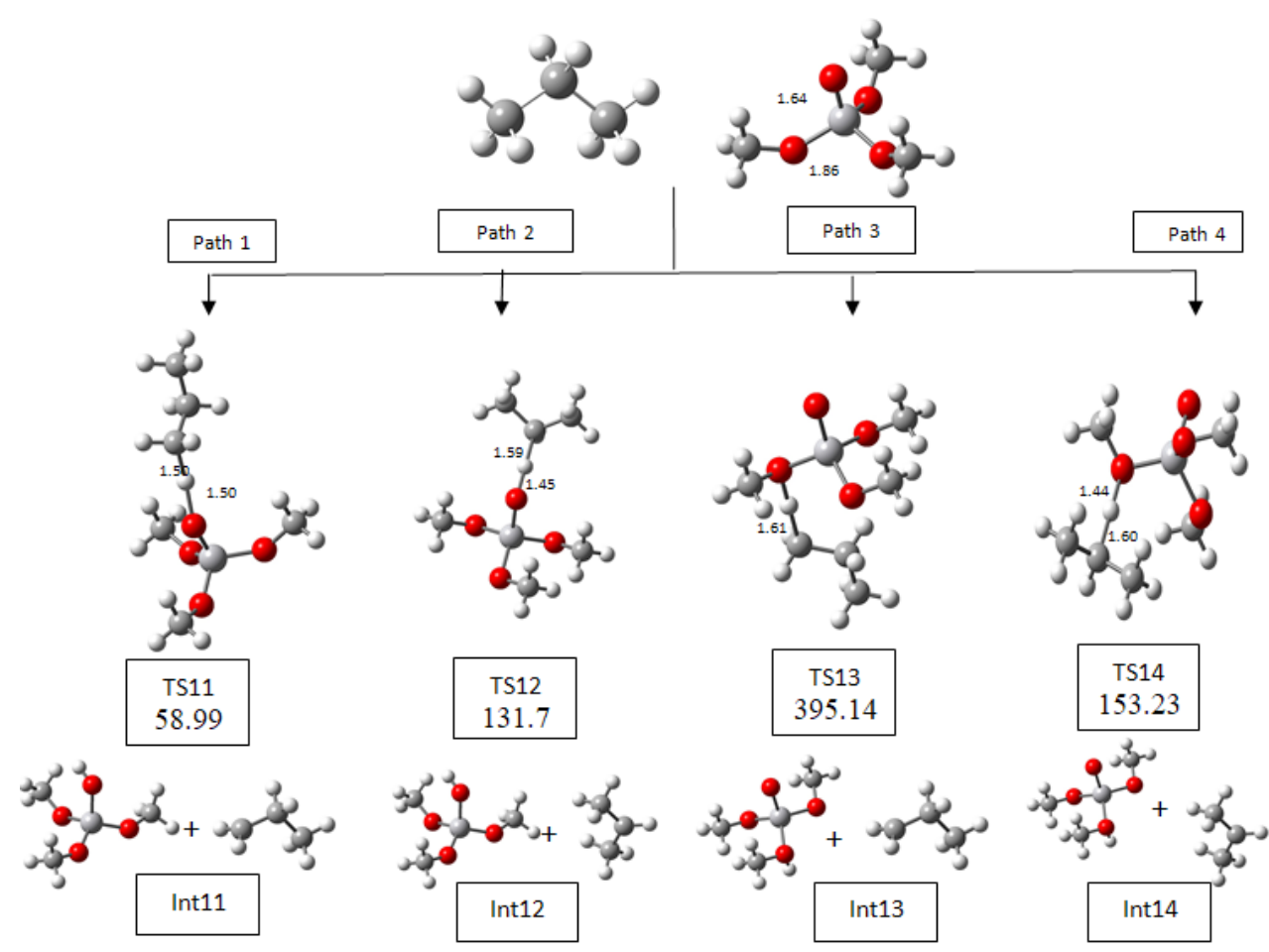

Figure 3. Reaction pathways and $(\Delta \mathrm{E}, \mathrm{kcal} / \mathrm{mol})$ for initial $\mathrm{C}-\mathrm{H}$ bond activation of propane (The bond distances are according to angstrom $(\AA)$ ).

elongates from 1.39 to $1.43 \AA$. The energy barrier for TS12 is equal $151.39 \mathrm{kcal} / \mathrm{mol}$. Vanadium hydride, propyl and isopropyl radicals are formed in the first intermediate in both reactions path (1) and (2) (Int11 and Int12). In vanadium hydride optimized geometry, the $\mathrm{H}-\mathrm{O} 1$, and $\mathrm{V}-\mathrm{O} 1$ bond distances are 0.95 and $1.79 \AA$, respectively. Path (3) and (4) include hydrogen abstraction reaction. In both path (3) and (4) the bridging oxygen 02 abstracts the hydrogen atom from the first and second type of carbon of propane respectively. The $\mathrm{O} 2-\mathrm{H}$ and $\mathrm{H}-\mathrm{C}$ bond distances in TS13 are 1.43 $\AA$ and $1.61 \AA$ respectively, $1.44 \AA$, and $1.60 \AA$ in TS14. The activation barrier for path (3) and (4) are about 123.86 and $143.38 \mathrm{kcal} / \mathrm{mol}$ respectively. The corresponding intermediate, Int13 and Int14 for path (3) and path (4) respectively have bond distances of $\mathrm{V}=01$ equal $1.86 \AA$, $\mathrm{V}-\mathrm{O} 2=$ $1.86 \AA$ and $\mathrm{C}-\mathrm{O}=1.43 \AA$. Comparison between different reaction paths indicate that path (1) with activation energy about $48.35 \mathrm{kcal} / \mathrm{mol}$, is the most energetically desirable and possible pathway among the four reaction pathways. In addition, hydrogen abstraction pathways are more favorable than the addition pathways. As the $\pi$ bond of $V=01$ has a singly occupied orbital available to bond to the $\mathrm{H}$ atom and pointing toward it, the obtained result seems reasonable, whereas for $\mathrm{O} 2$ atom the orbital overlapping the $\mathrm{H}$ is a filled lone pair orbital.

In conclusion, the hydrogen abstraction reactions have the $\sigma$-orbital of $\mathrm{C}-\mathrm{H}$ bond aligned with the lone pair electrons orbital of $\mathrm{O} 1$ or $\mathrm{O} 2$ atoms. However, the addition reaction needs $\sigma^{-}$ orbital of $\mathrm{C}-\mathrm{H}$ bond in propane to break almost completely before it can overlap with the filled lone pair orbital on oxygen atom and the empty d-orbital on vanadium, cause to a high barrier. In the case of the $\mathrm{C}-\mathrm{H}$ bond activation of propane on the $\mathrm{VO}_{4}\left(\mathrm{CH}_{3}\right)_{3}$ model, this conclusion is taken that hydrogen abstraction by $\mathrm{O} 1$ atom is the first common step for alkane ODH reaction, hence it can be considered as the initial step for the propane ODH mechanism.

\section{Abstraction of the Second Hydrogen from Propylene}

The optimized structure of the intermediate1 from path (1), Int11, is considered as the initial point for the final part of the mechanism, dissociation of product and catalyst reoxidation, Figure 4 . There are three possible reaction paths to propene 


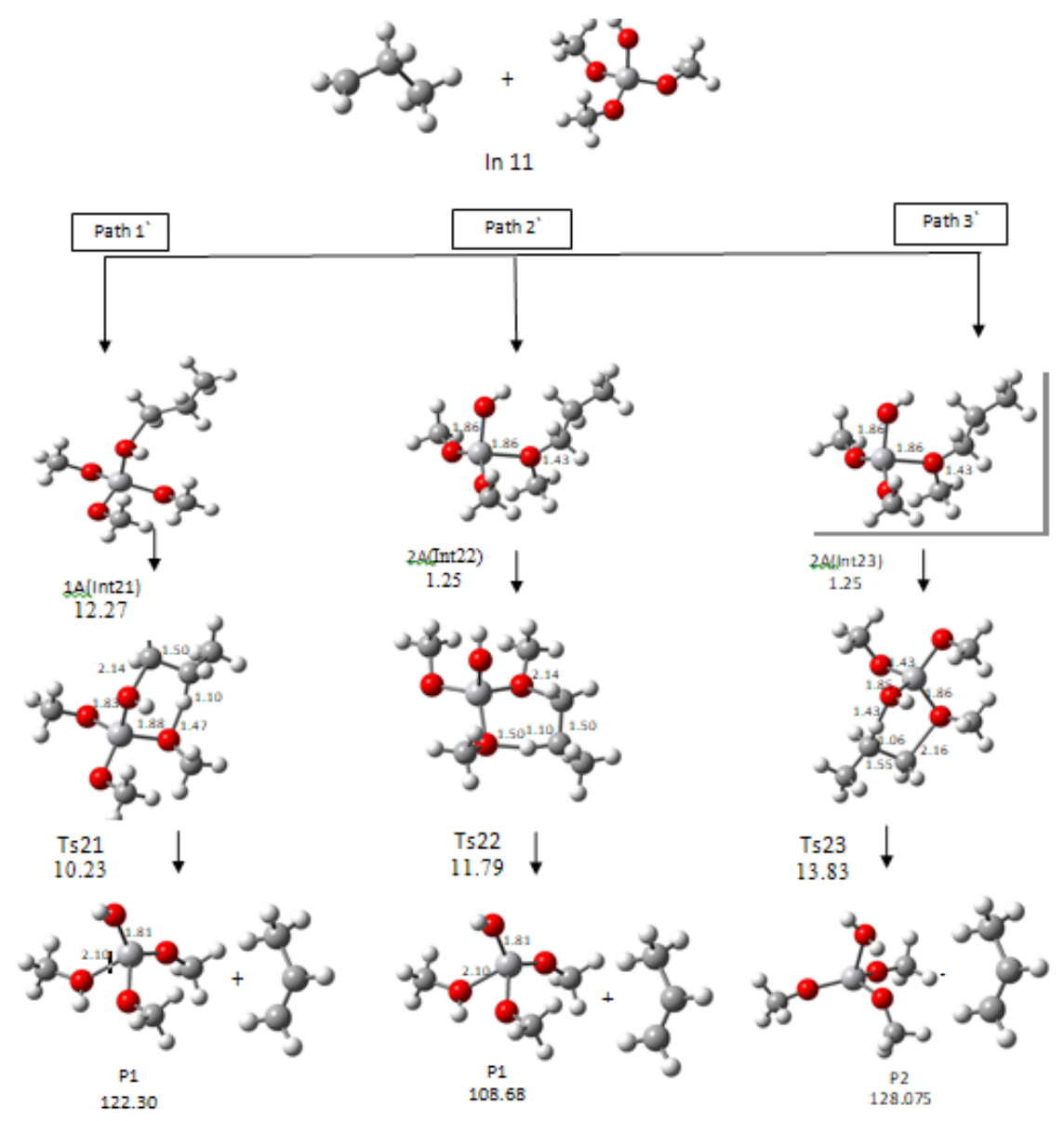

Figure 4. Presentation of three different reaction pathways for binding of propyl radical to the $\mathrm{VO}_{4} \mathrm{H}_{(}\left(\mathrm{CH}_{3}\right)_{3}$ followed by the second hydrogen abstraction to release the propene product, the first row of the energetic parameters is $\Delta \mathrm{E}$, kcal/ mol (the bond distances are according to angstrom $(\AA)$ ).

formation, $\mathrm{O} 2, \mathrm{O} 1-\mathrm{H}$ are used with the aim of abstracting the second hydrogen from a methyl group to form propene and $\mathrm{VO}_{4} \mathrm{H}_{2}\left(\mathrm{CH}_{3}\right)_{3}$ catalyst. In Path (1'), the propyl radical binds to the $\mathrm{O} 1-\mathrm{H}$ group to form second intermediate, Int21 (1A), which is $106.17 \mathrm{kcal} / \mathrm{mol}$ more stable than Int11. In the final step in Path 1', 02 abstracts the second hydrogen from the methyl group, leading to propene and $\mathrm{P} 1$ by passing to second transition state, Ts21, with an activation barrier of -96.18 $\mathrm{kcal} / \mathrm{mol}$. Paths 2' and 3' start with the formation of the same intermediate, Int22 and Int23, (2A), via a bond which is formed between the propyl radical and $\mathrm{O} 2$ atom. In Path 2', 01 abstracts one hydrogen from the methyl group with a -82.76 $\mathrm{kcal} / \mathrm{mol}$ barrier to form propene and P1 via TS22. Path (3) (Hydroxyl-H 2nd-abs step), starting from the same intermediate, 2A (Int23), uses the $01-\mathrm{H}$ group to abstract a hydrogen atom from the methyl group, leading to the formation of propene and P2, with about $-170.35 \mathrm{kcal} / \mathrm{mol}$ barrier (Ts23).
In the Ts23 structure, the bond distance of V-01 decreases from $1.86 \AA$ in Int23 (2A) to $1.84 \AA$, while the $\mathrm{V}-\mathrm{O} 2$ bond distance decreases from 1.86 $\AA$ to $1.84 \AA$. Path 2 has the lowest reaction barrier among the three possible reaction pathways studied in this work, $-82.76 \mathrm{kcal} / \mathrm{mol}$ but path $3^{\prime}$ is more favorable than other paths because $\mathrm{H}_{2} \mathrm{O}$ easily released from $\mathrm{P} 2$ than $\mathrm{P} 1$. The representative potential energy profile of the total reaction was obtained and is shown in Figure 5.

\section{Vanadium Reoxidation}

The most favorable step, path (3)' lead to P2 product that we consider as the starting point for the final section of the mechanism, dissociation of the product and catalyst reoxidation. It is expected that water would easily dissociate from P2 to create a vacant VIII site. However, the dissociation energy calculated $60.5 \mathrm{kcal} / \mathrm{mol}$, which is higher than the activation barriers for 


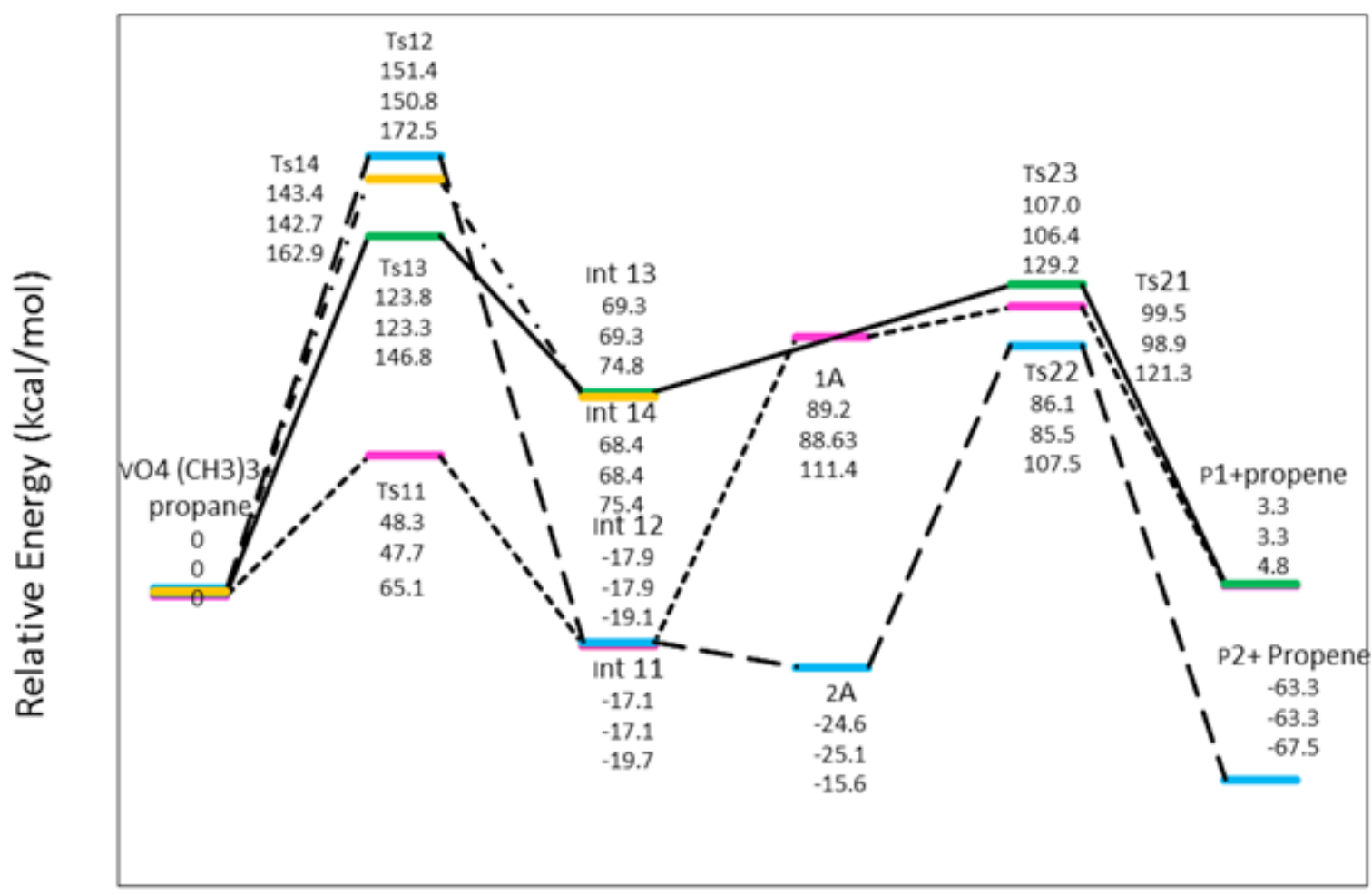

Figure 5. Calculated energy profiles for propane ODH on $\mathrm{VO}_{4}\left(\mathrm{CH}_{3}\right)_{3}$, the first row of the energetic parameters is $\Delta \mathrm{E}_{298^{\prime}}$ the second row is $\Delta \mathrm{H}_{298}$ and the third row is $\Delta \mathrm{G}_{298}$ respectively.

the conversion of propane to propene. Instead, we used another associative mechanism where water dissociation is assisted by the oxidant, $\mathrm{O}_{2}$. In this mechanism, at first, $\mathrm{O}_{2}$ binds to $\mathrm{P} 2$ with 2.0 $\mathrm{kcal} / \mathrm{mol}$ for bonding of dioxygen to $\mathrm{P} 2$ eventually resulting in the $\mathrm{VO}_{3}\left(\mathrm{CH}_{3}\right)_{3} \mathrm{O}_{2} \mathrm{H}_{2}$ (complex1-Figure $6)$, which can be considered as a complex of $\mathrm{VO}_{3}\left(\mathrm{CH}_{3}\right)_{3} \mathrm{O}_{2}$ (complex 2-Figure 6) and water. In complex 1 the $\mathrm{VOO}$ forms cyclic peroxide.

To take the VoO plane as $x z$, this involves rehybridizing the $d z 2$ and $d x z$ orbitals on the $V$ atom to obtain orbitals which can spin pair directly with the pz orbitals on each oxygen atom to form VO bonds. The $\mathrm{H}_{2} \mathrm{O}$ lone pair keeps coordinating to the empty dyz orbital of the $\mathrm{V}$, and the $\mathrm{V}-\mathrm{OH}_{2}$ bond distance in complex 1 is $4.2 \AA$, that is 2.06 $\AA$ longer than in $\mathrm{P} 2$, indicating a dramatically weakened bond. In the second step, $\mathrm{H}_{2} \mathrm{O}$ has been desorbed from complex 1 to form complex 2 . Binding $\mathrm{O}_{2}$ to $\mathrm{P} 2$ has the effect of destabilizing the bonding of $\mathrm{H}_{2} \mathrm{O}$. Thus, the energy to desorb $\mathrm{H}_{2} \mathrm{O}$ from complex 1 is only $8.56 \mathrm{kcal} / \mathrm{mol}$ (rather than the $37.42 \mathrm{kcal} / \mathrm{mol}$ from $\mathrm{P} 2$ ).
In the third step, complex 2 converts to reform the initial catalyst, $\mathrm{VO}_{4}\left(\mathrm{CH}_{3}\right)_{3}$. In order to accomplish the catalytic cycle, the proxy specie 2 must be converted back to the initial $\mathrm{VO}_{4}\left(\mathrm{CH}_{3}\right)_{3}$ complex. As we expected, complex 2 would be more reactive than the initial model catalyst, $\mathrm{VO}_{4}\left(\mathrm{CH}_{3}\right)_{3}$. However, bonding an hydrogen atom to complex 2 to form a bound $\mathrm{V}-\mathrm{OOH}$ gains $12.81 \mathrm{kcal} / \mathrm{mol}$, as compared to $60.79 \mathrm{kcal} / \mathrm{mol}$ for bonding $\mathrm{H}$ to the $\mathrm{V}=\mathrm{O} 1$ of $\mathrm{VO}_{4}\left(\mathrm{CH}_{3}\right)_{3}$, indicating more reactivity. We have hypothesized that complex 2 might activate a second propane instead. We use an easy hydrogen abstraction mechanism by using peroxo moiety with a calculated barrier of $23.66 \mathrm{kcal} / \mathrm{mol}$, lower than the barrier for the initial hydrogen abstraction step (Ts12) using the $\mathrm{VO}_{4}\left(\mathrm{CH}_{3}\right)_{3}$ catalyst (with $49.35 \mathrm{kcal} / \mathrm{mol}$ barrier energy). In the subsequent step, the propyl radical fragment in complex 3 bonds with the other oxygen atom of the peroxo group to form complex 4 with 23.8 $\mathrm{Kcal} / \mathrm{mol}$ barrier. The second molecule of propene and water are formed by passing through a sixmembered ring transition state, Ts 4-1 (Figure 6). For this step, the activation energy is $23.1 \mathrm{kcal} /$ 
mol. The initial $\mathrm{VO}_{4}\left(\mathrm{CH}_{3}\right)_{3}$ catalyst is regenerated, completing the catalytic cycle. Catalyst cycle is summarized in Figure 7, schematically.

The potential energy surface for this cycle is shown in Figure 8 . The overall reaction is:

$\mathrm{VO}_{4}\left(\mathrm{CH}_{3}\right)_{3}+2 \mathrm{C}_{3} \mathrm{H}_{8}+\mathrm{O}_{2} \rightarrow \mathrm{VO}_{4}\left(\mathrm{CH}_{3}\right)_{3}+2 \mathrm{C}_{3} \mathrm{H}_{6}+2 \mathrm{H}_{2} \mathrm{O}$ $\Delta \mathrm{E}=-28.0 \mathrm{kcal} / \mathrm{mol}$

In the above mentioned catalytic cycle, the $\mathrm{V}=01$ is the active site for all steps however $\mathrm{O}_{2}$ only playing the role of stabilizing the propyl radical by forming the stable intermediate.

\section{CONCLUSION}

The ODHP reaction over a vanadium-carbon catalyst by using DFT method was investigated in order to study the oxidative reaction and possible pathways in detail. We have applied $\mathrm{VO}_{4}\left(\mathrm{CH}_{3}\right)_{3}$ model for studding the catalysis on $\mathrm{V}$ supported $\mathrm{C}$ (as carbon structure). The initial step is hydrogen abstraction from propane by cooperation of both terminal and interface oxygen sites for the first and second $\mathrm{C}-\mathrm{H}$ activation, respectively. The second step initiates with propoxide intermediate on the 01 site of $\mathrm{VO}_{4}\left(\mathrm{CH}_{3}\right)_{3}$. There are three competitive reaction pathways leading to the formation of the propene as product. The complete catalytic cycle for conversion of propane to propene on $\mathrm{VO}_{4}\left(\mathrm{CH}_{3}\right)_{3}$ including reoxidation of the active site is reported here. Consequently, we have proposed that the rate determining step corresponds to the first hydrogen abstraction. In our catalytic cycle, gaseous $\mathrm{O}_{2}$ promotes water desorption and reoxidizing the reduced vanadium oxide catalyst. Our calculated results predicted that complex 2 (Figure 6) activate the methylene $\mathrm{C}-\mathrm{H}$ bond in propane with a reaction barrier 14.7. As the $\mathrm{C}-\mathrm{H}$ bond of propene product is weaker than the $\mathrm{H}$-iPr bond in propane, the $V=O$ (1) sites could react more rapidly with the product than reactant, leads to some products such as $\mathrm{CO}_{2}$. With the purpose of avoiding such disadvantages in selectivity process, the product should be protected from $V=0$ sites. This might be the reason of high selectivity property of supported catalysts. In catalytic cycle, the $\mathrm{V}=01$ sites play an essential role in all reaction steps, while bridging oxygens ( $\mathrm{V}-\mathrm{O}-\mathrm{C})$ play the stabilizing role in the propyl intermediate. This study reveals that the activity

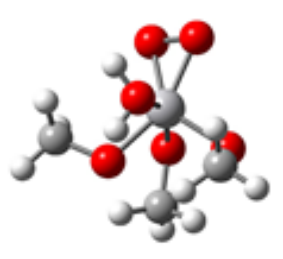

1

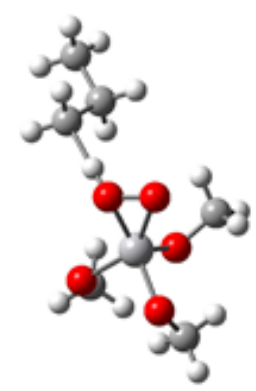

3

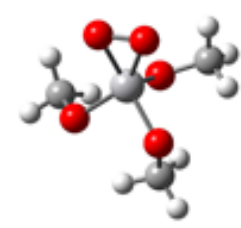

2

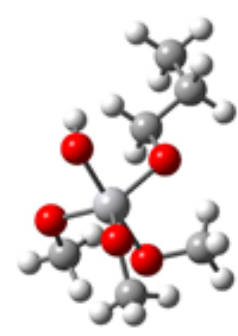

4

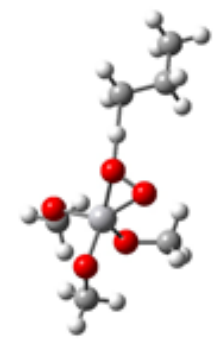

Ts 2-1

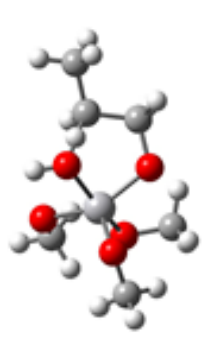

Ts 4-1

Figure 6. Presentation of optimized structures for the intermediate and transition states of the vanadium reoxidation step. 


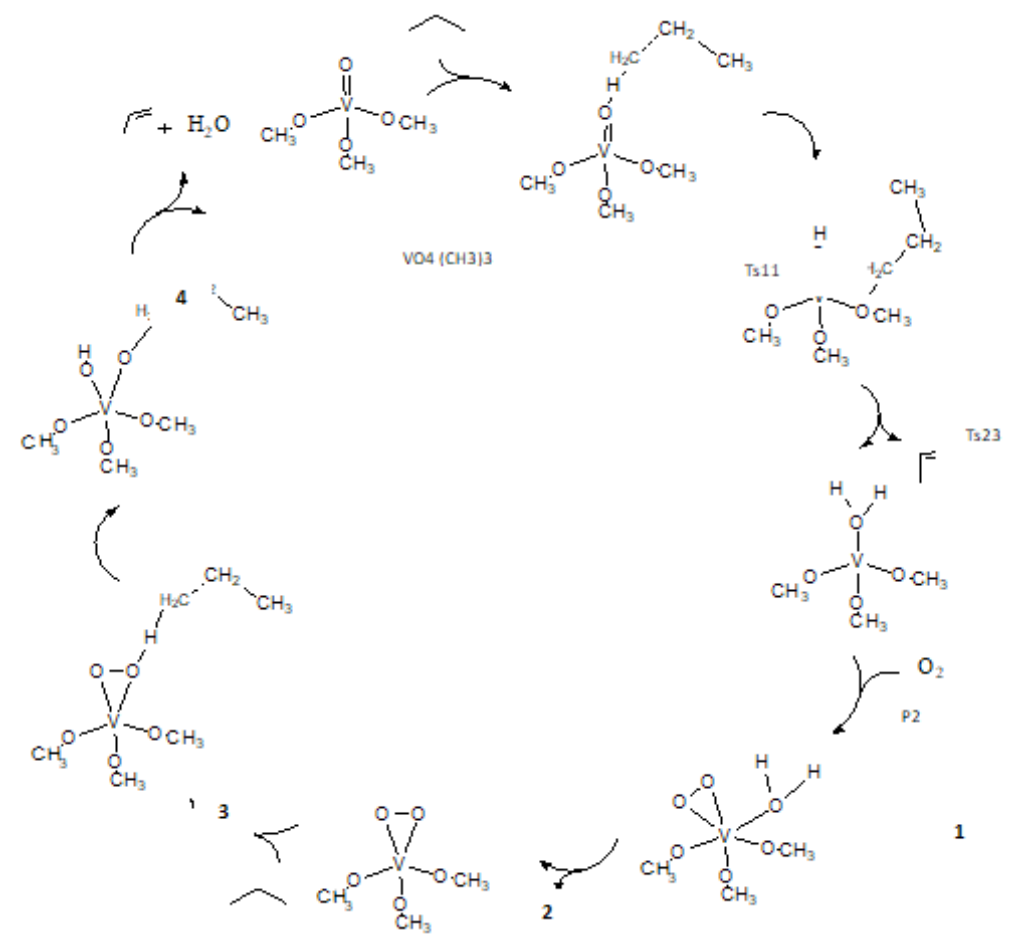

Figure 7. The proposed catalylic cycle for propane ODH on $\mathrm{VO}_{4}\left(\mathrm{CH}_{3}\right)_{3}$ derived from the Quantum mechanical calculations.

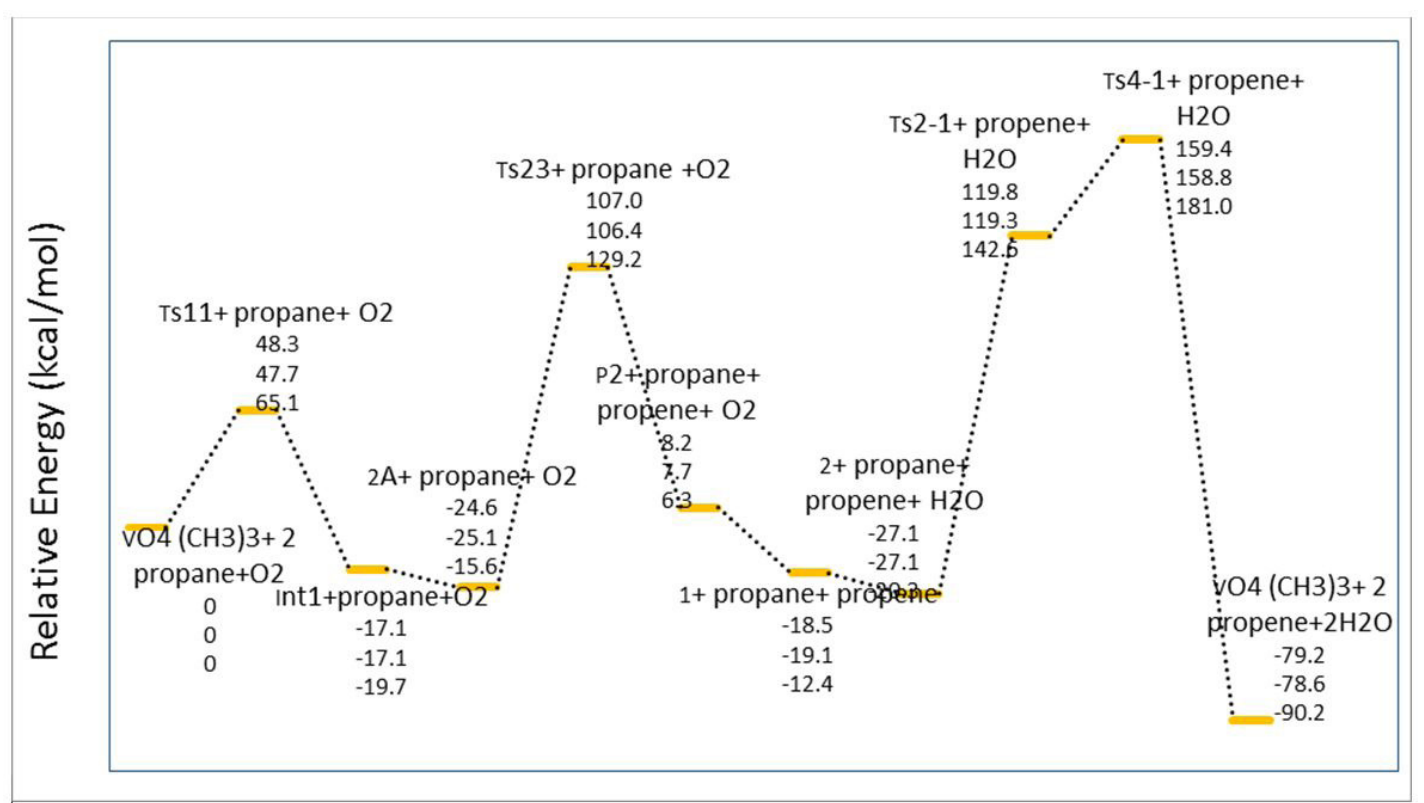

Figure 8. Energy profiles of the single-site vanadyl activation and reoxidation catalytic cycle for propane ODH on $\mathrm{VO}_{4}\left(\mathrm{CH}_{3}\right)_{3}$, The first row of the energetic parameters is $\Delta \mathrm{E}_{298}$, the second row is $\Delta \mathrm{H}_{298}$ and the third row is $\Delta G_{298}$ respectively.

and selectivity of $\mathrm{ODH}$ reaction is correlated to the structure and surface chemistry of carbon materials based on the proposed reaction mechanism. Our results may inspire application of 13 this process for carbon materials and in experimental reactions, as well. More DFT studies in future are highly recommended, which could make better rational design of the catalysts to achieve better selectivity, hence better results. 


\section{ACKNOWLEDGEMENTS}

The authors gratefully acknowledge research council of Alzahra and Guilan Universities.

\section{References}

1. X. Rozanska, R. Fortrie, J. Sauer, Oxidative dehydrogenation of propane by monomeric vanadium oxide sites on silica support, J. Phys. Chem. C., 111 (2007) 6041-6050.

2. B. Frank, M. Morassutto, R. Schomäcker, R. Schlögl, D.S. Su, Oxidative dehydrogenation of ethane over multiwalled carbon nanotubes, ChemCatChem., 2 (2010) 644-648.

3. B. Frank, J. Zhang, R. Blume, R. Schlögl, D.S. Su, Heteroatoms increase the selectivity in oxidative dehydrogenation reactions on nanocarbons, Angew. Chem. Int. Ed., 48 (2009) 6913-6917.

4. J. Zhang, X. Liu, R. Blume, A. Zhang, R. Schlögl, D.S. Su, Surface-modified carbon nanotubes catalyze oxidative dehydrogenation of n-butane, Science, 322 (2008) 7377.

5. C. Liang, H. Xie, V. Schwartz, J. Howe, S. Dai, S.H. Overbury, Open-Cage fullerene-like graphitic carbons as catalysts for oxidative dehydrogenation of isobutane, J. Am. Chem. Soc., 131 (2009) 7735-7741.

6. T. García, J. López, J.L. Nieto, R. Sanchis, A. Dejoz, M. Vázquez, B. Solsona, Insights into the catalytic production of hydrogen from propane in the presence of oxygen: Cooperative presence of vanadium and gold catalysts, Fuel Process. Technol., 134 (2015) 290296.

7. M. Sheintuch, D.S. Simakov, Alkanes dehydrogenation, membrane reactors for hydrogen production processes, Springer, (2011) 183-200.

8. B. Barghi, M. Fattahi, F. Khorasheh, Kinetic modeling of propane dehydrogenation over an industrial catalyst in the presence of oxygenated compounds, reaction kinetics, React. Kinet. Mech. Cat., 107 (2012) 141-155.

9. S.A. Al-Ghamdi, H.I. de Lasa, Propylene production via propane oxidative dehydrogenation over $\mathrm{VOx} / \gamma-\mathrm{Al}_{2} \mathrm{O}_{3}$ catalyst, Fuel, 128 (2014) 120-140.

10. H. Kim, G.A. Ferguson, L. Cheng, S.A. Zygmunt, P.C. Stair, L.A. Curtiss, Structure-specific reactivity of alumina-supported monomeric vanadium oxide species, J. Phys. Chem. C, 116 (2012) 2927-2932.

11. C. Popa, M.V. Ganduglia-Pirovano, J. Sauer, Periodic density functional theory study of von species supported on the $\mathrm{CeO}_{2}$ surface, J. Phys. Chem. C, 115 (2011) 7399-7410.

12. M.J. Cheng, K. Chenoweth, J. Oxgaard, A. van Duin, W.A. Goddard, Single-site vanadyl activation functionalization, and reoxidation reaction mechanism for propane oxidative dehydrogenation on the cubic v4010 cluster, J. Phys. Chem. C, 111 (2007) 5115-5127.

13. M.V. Ganduglia-Pirovano, C. Popa, J. Sauer, H. Abbott, A. Uhl, M. Baron, D. Stacchiola, O. Bondarchuk, S. Shaikhutdinov, H.J. Freund, Role of ceria in oxidative dehydrogenation on supported vanadia catalysts, J. Am. Chem. Soc., 132 (2010) 2345-2349.
14. X. Fan, G. Zhang, F. Zhang, Multiple roles of graphene in heterogeneous catalysis, Chem. Soc. Rev., 44 (2015) 3023-3035.

15. O.V. Khavryuchenko, B. Frank, A. Trunschke, K. Hermann, R. Schlögl, Quantum-chemical investigation of hydrocarbon oxidative dehydrogenation over spinactive carbon catalyst clusters, J. Phys. Chem. C, 117 (2013) 6225-6234.

16. B. Frank, R. Blume, A. Rinaldi, A. Trunschke, Oxygen insertion catalysis by $\mathrm{sp}^{2}$ carbon, R. Schlögl, Angew. Chem. Int. Ed., 50 (2011) 10226-10230.

17. F. Cavani, F. Trifiro, The oxidative dehydrogenation of ethane and propane as an alternative way for the production of light olefins, Catal. Today, 24 (1995) 307-313.

18. M.D. Argyle, K. Chen, A.T. Bell, E. Iglesia, Effect of catalyst structure on oxidative dehydrogenation of ethane and propane on alumina-supported vanadia, J. Catal., 208 (2002) 139-149.

19. D. Whitehurst, Abstracts of papers of the American Chemical Society, Am. Chem. Soc., 1155 16TH ST, NW, Washington, DC 20036, 1997, pp. 77-FUEL.

20. E. Mamedov, V.C. Corberán, Oxidative dehydrogenation of lower alkanes on vanadium oxide-based catalysts. The present state of the art and outlooks, Appl. Catal. A-Gen., 127 (1995) 1-40.

21. A.S. Kootenaei, J. Towfighi, A. Khodadadi, Y. Mortazavi, Stability and catalytic performance of vanadia supported on nanostructured titania catalyst in oxidative dehydrogenation of propane, Appl. Surf. Sci., 298 (2014) 26-35

22. M. Calatayud, B. Mguig, C. Minot, A periodic model for the $\mathrm{V}_{2} \mathrm{O}_{5}-\mathrm{TiO}_{2}$ (anatase) catalyst. stability of dimeric species, Surf. Sci., 526 (2003) 297-308.

23. M. Calatayud, B. Mguig, C. Minot, A DFT study on the hydrated $\mathrm{V}_{2} \mathrm{O}_{5}-\mathrm{TiO}_{2}$-anatase catalyst: stability of monomeric species, Theor. Chem. Acc., 114 (2005) 2937.

24. M. Calatayud, C. Minot, Reactivity of the $\mathrm{V}_{2} \mathrm{O}_{5}-\mathrm{TiO}_{2}-$ anatase catalyst: role of the oxygen sites, Top. Catal., 41 (2006) 17-26.

25. C.A. Carrero, R. Schlögl, I.E. Wachs, R. Schomaecker, Critical literature review of the kinetics for the oxidative dehydrogenation of propane over welldefined supported vanadium oxide catalysts, ACS Catal., 4 (2014) 3357-3380.

26. B. Hammer, J.K. Nørskov, Theoretical surface science and catalysis-calculations and concepts, Adv. Catal., 45 (2000) 71-129.

27. J.K. Nørskov, T. Bligaard, J. Rossmeisl, C.H. Christensen, Towards the computational design of solid catalysts, Nature Chem., 1 (2009) 37-46.

28. B. Frank, S. Wrabetz, O.V. Khavryuchenko, R. Blume, A. Trunschke, R. Schlögl, Calorimetric study of propane and propylene adsorption on the active surface of multiwalled carbon nanotube catalysts, Chem. Phys. Chem., 12 (2011) 2709-2713.

29. W. Daniell, A. Ponchel, S. Kuba, F. Anderle, T. Weingand, D. Gregory, H. Knözinger, Characterization and catalytic behavior of $\mathrm{VO}_{x}-\mathrm{CeO}_{2}$ catalysts for the oxidative dehydrogenation of propane, Top. Catal., 20 (2002) 65-74.

30. A. Khodakov, B. Olthof, A.T. Bell, E. Iglesia, Structure and catalytic properties of supported vanadium oxides: support effects on oxidative dehydrogenation reactions, J. Catal., 181 (1999) 205-216. 
31. S.T. Oyama, Adsorbate bonding and the selection of partial and total oxidation pathways, J. Catal., 128 (1991) 210-217.

32. J. Le Bars, J. Vedrine, A. Auroux, B. Pommier, G. Pajonk, Calorimetric study of vanadium pentoxide catalysts used in the reaction of ethane oxidative dehydrogenation, J. Phys. Chem., 96 (1992) 2217-2221.

33. H.H. Kung, Oxidative dehydrogenation of light (C2 to C4) Alkanes, Adv. catal. 40 (1994) 1-38.

34. C. Pieck, M. Banares, J. Fierro, Propane oxidative dehydrogenation on $\mathrm{VO}_{x} / \mathrm{ZrO}_{2}$ catalysts, J. Catal., 224 (2004) 1-7.

35. A.D. Becke, Density functional thermochemistry, III the role of exact exchange, J. Chem. Phys., 98 (1993) 5648-5652.
36. R.G. Parr, W. Yang, Density-Functional Theory of atoms and molecules, Oxford University Press, 1989.

37. R. Enjalbert, J. Galy, A refinement of the structure of $\mathrm{V}_{2} \mathrm{O}_{5}$, Acta. Cryst. Sect. C: Cryst. Struct. Commun., 42 (1986) 1467-1469.

38. M. Ganduglia-Pirovano, J. Sauer, Stability of reduced $\mathrm{V}_{2} \mathrm{O}_{5}$ (001) Surfaces, Phys. Rev. B, 70 (2004) 0454221-045422-13.

39. S.T. Oyama, G.T. Went, K.B. Lewis, A.T. Bell, G.A. Somorjai, Oxygen chemisorption and laser Raman spectroscopy of unsupported and silica-supported vanadium oxide catalysts, J. Phys. Chem., 93 (1989) 6786-6790. 
